\begin{tabular}{|l|l|l|}
\hline \multicolumn{2}{|c|}{ PublisherInfo } \\
\hline \hline PublisherName & $:$ & BioMed Central \\
\hline \hline PublisherLocation & $:$ & London \\
\hline \hline PublisherImprintName & $:$ & BioMed Central \\
\hline \hline
\end{tabular}

\title{
Proteome chips and protein function
}

\begin{tabular}{|l|l|l||}
\hline \multicolumn{2}{|c||}{ ArticleInfo } \\
\hline \hline ArticleID & $:$ & 3885 \\
\hline \hline ArticleDOI & $:$ & $10.1186 /$ gb-2001-2-10-reports0035 \\
\hline \hline ArticleCitationID & $:$ & reports0035 \\
\hline \hline ArticleSequenceNumber & $:$ & 17 \\
\hline \hline ArticleCategory & $:$ & Paper report \\
\hline \hline ArticleFirstPage & $:$ & 1 \\
\hline \hline ArticleLastPage & $:$ & 4 \\
\hline \hline & & RegistrationDate : 2001-8-7 \\
ArticleHistory & $:$ & Received \\
\hline ArticleCopyright & $:$ & BioMed Central Ltd2001 \\
\hline \hline ArticleGrants & $:$ & \\
\hline \hline
\end{tabular}




\begin{tabular}{|l|l|l||}
\hline ArticleContext & $: 13059221010$ \\
\hline
\end{tabular}

\section{Reiner Veitia}

\section{Abstract}

A 'protein chip' incorporating most of the yeast proteome can be used for the high-throughput characterization of proteins.

\section{Significance and context}

Although the word genome was coined to refer to the genetic material, the meaning of genomics has widened to cover analysis of both RNA and proteins. Earlier functional genomics studies focused on RNA expression, with high-throughput analysis achieved by the immobilization of myriad cDNAs on a solid surface, such as a microscope slide - a 'DNA chip'. But, as the biological components acting in cell function are mostly proteins, we must study the proteome - the proteins expressed from a genome - to fully understand a living organism. Purified proteins can now be immobilized at high density on flat surfaces to give 'protein chips', which will aid high-throughput characterization of the biochemical and functional properties of cellular proteins.

\section{Key results}

Zhu et al. have expressed 5,800 yeast open reading frames (ORFs), encoding about 80\% of the yeast proteome, as fusion proteins (fusions with glutathione- $S$-transferase, GST, and a histidine tag, His6). The proteins were expressed in yeast, to ensure proper folding and posttranslational modification, and were detergent-extracted. Random protein samples were then analyzed for quality and quantity by immunoblotting. The 5,800 different proteins were printed in duplicate onto glass slides using a commercial microarrayer. The authors decided on nickel-coated slides, which retain the proteins by interacting with the histidine tags. They were able to spot 13,000 protein samples in half the area of a standard glass microscope slide.

The resulting yeast protein chip was tested by probing for protein-protein interactions and proteinlipid interactions. On probing with biotinylated calmodulin (a regulatory calcium-binding protein), for example, the authors detected six known calmodulin partners and an additional 33 potentially interacting proteins. Sequence pattern searches revealed that 14 of these 39 polypeptides had a particular protein motif thought to be responsible for their interaction with calmodulin. Four more known calmodulin partners went undetected in this experiment, for unknown reasons. The negative control, using 
streptavidin alone as the probe, was positive for Pyclp, a pyruvate carboxylase homolog that contains a conserved biotin-attachment site; this showed that Pyc1 protein is indeed biotinylated in vivo.

In looking for protein-lipid interactions, Zhu et al. focused on phosphatidylinositol (PI)-binding proteins. As probes they prepared phosphatidylcholine (PC) liposomes that also included several phosphorylated forms of PIs and a biotinylated lipid. When tested against the protein chip, a total of 150 'above-background' signals were obtained. These included known membrane proteins as well as uncharacterized polypeptides. The authors sorted the responding proteins according to the strength of their interactions and also characterized them by lipid preference and specificity.

\section{Conclusions}

The construction of a 'proteome chip' is technically feasible, and such chips can be used to study protein-protein and protein-lipid interactions. The authors recognize that their approach, although very useful, has limitations. For example, there is the possibility of indirect interactions due to contaminating peptides co-purifying with the immobilized protein. Given the stringency of the purification process, however, most of the proteins that are printed are presumed to be single polypeptides. The authors also note that properly folded secreted proteins might be under-represented, as the GST sequence and the histidine tag are fused at the amino terminus of the protein sequence, where a signal peptide would be.

\section{Reporter's comments}

The system developed by Zhu et al. could be used to study interactions between immobilized proteins and other molecules such as therapeutic agents, if the interactions are strong enough to be detectable and if one can find a way to stabilize the complexes. In future, to give a more realistic picture of interactions, the environment of the immobilized proteins will need to reproduce in vivo conditions better. How, for example, does an integral membrane protein properly fold if surrounded only by detergent, without the lipids that help it attain its normal conformation? There may also be interactions that go undetected under stringent experimental conditions; if protein A interacts only weakly with its partners $\mathrm{B}$ and $\mathrm{C}$ but more strongly with a BC complex, single interactions will be undetectable unless stabilized by agents able to crosslink the interacting proteins. Might we soon have thousands of well-characterized antibodies directed against every component of a proteome? To compare protein expression in different cellular states, one would simply label the proteins in one state with one fluorochrome and those in the other with another color. Then antigen-antibody interactions will magically deliver a complete picture.

\section{Table of links}


Science

\section{References}

1. Zhu H, Bilgin M, Bangham R, Hall D, Casamayor A, Bertone P, Lan N, Jansen R, Bidlingmaier S, Houfek T, et al: Global analysis of protein activities using proteome chips. Science. 2001, 293:

2101-2105. 0036-8075

This PDF file was created after publication. 